\title{
SYSTEMATIZATION OF INTERNATIONAL EXPERIENCE OF ENSURING ECONOMIC SECURITY OF EXACERBATION OF THE THREATS AND CHALLENGES OF A NEW TYPE FOR NATIONAL AND INTERNATIONAL SECURITY
}

\author{
Tatyana MOMOT ${ }^{1}$, \\ O.M. Beketov National University of Urban Economy, Ukraine \\ Nina AVANESOVA², \\ Kharkiv National University of Construction and Architecture, Ukraine
}

\begin{abstract}
The aim of the work is to systematize the international experience of economic security both in terms of individual countries and the global economy as a whole. Setting such a goal it is associated with the growth of globalization and integration processes in the world economy, which are the new threat of economic security. Methods. Theoretical and methodological basis of the study were research and findings on issues of economic security at the level of the world economy as a whole and individual national economies in particular. We used such general scientific and special methods, such as analysis and synthesis, comparison, generalization, adaptation. The findings led to the conclusion that the protection of national interests and the formation of an economic security strategy - the most important functions of the state, the implementation of which is impossible without a system of self-regulation mechanisms and regulation. The government should implement a set of measures to promote economic growth, and that will guarantee the economic security of the country. These measures should cover all sectors of the economy. These measures include the implementation an active structural and social policies, enhancing the activity of the state in investment, financial, monetary and foreign economic sphere, the continuation of institutional reforms. The practical significance is to separate the differences used methodological approaches to ensure the economic security of the EU member countries and the CIS. This is explained by the fact that the first group of countries is focused on standards and borrows the experience of the leading EU countries (Germany, France), and the second group, located in the zone of influence of Russia (Moldova, Ukraine, Belarus, Kazakhstan), - on the Russian developments and standards. In turn, Russia in their design focuses more on standards to ensure economic security, which have been made in the period of the Soviet Union. Value/originality. The results obtained allowed to identify the main strategic goal of the Western European countries, the USA, Canada and Japan in the field of protection of national economic interests, which is understood as sustainable economic growth and modernization of the economy in accordance with the conditions of competition on the world market.
\end{abstract}

Key words: globalization, economic security, national economy, global economy, strategies of economic security.

JEL Classification: F01, F29, F52, F69

\section{Introduction}

At the core of the trends of modern international relations is the world of the XXI century the concept - it's agreed principles of relations between states in the international arena, which will contribute to the establishment of peace, without violence, ensure comprehensive security, transition states and regions to sustainable development, building on the planet of a harmonious civilization, consisting of various states, nation, culture, religion.
Globalization is the main tool for the implementation of this concept, but it causes a lot of conflict in international relations, which are the most relevant at the present stage.

Globalisation - an objective phenomenon that does not depend on the will of individuals. The processes of globalization are now deepened and spread with increasing speed.

The certain objective conditions of modern development. No country, no economy, no society cannot remain aloof from these processes. They are

\footnotetext{
Corresponding author:

${ }^{1}$ Department of Finance and Economic Security, Accounting and Audit, O.M. Beketov National University of Urban Economy.

E-mail: tvmomot@gmail.com

${ }^{2}$ Department of Finance and Credit, Kharkiv National University of Construction and Architecture.

E-mail: avanesova@i.ua
} 
connected with the peculiarities of the approval of the post-industrial production technology, the deepening international division of labour, internationalization in modern conditions the main types of industrial activity, the dramatic changes in the information sphere, increasing interdependence among countries, the socialization of economic processes, the democratization of political institutions, the internationalization of public life, the convergence of spiritual values that humanity stands.

On a global scale, globalization is reflected in the growing interconnection and interdependence of the world's population in the various fields of activity. This process combines the economy, politics, culture and information sector, technology and management. This convergence was made possible by the accumulation of enormous humanity's material and spiritual values, which create an objective basis for the development of modern civilization process no matter what socio-state form it acquires. The idea is that the accumulation of human values in economics, politics, science, culture, morality eventually became more important than the achievements in these areas, certain state-national entities.

The main problem that has arisen in the course of globalization, in terms of maintaining state sovereignty, is the contradiction between the growing political and economic interdependence of countries and peoples on the one hand, and the preservation of a public right to own and at their own discretion to decide their own problems on the other. Due to the progressive erosion of the boundaries between the national economies of the problems previously considered exclusively foreign, are increasingly becoming an integrated international internal political character. Government actions of one country can lead to very serious consequences on the other side of the globe. In these circumstances, it becomes evident the need to harmonize responsible decisions, and hence the establishment of appropriate institutional arrangements. And the process of establishing such mechanisms is very intensive. If in 1909 there were 37 intergovernmental organizations, at the end of the century it has become 260. International is organizations such as the EU, the WTO, NAFTA, MERCOSUR and several others, taking on some of the functions delegated to them by individual States, effectively limiting sovereignty. Loosening the foundations of state sovereignty it is directly related to the aggravation of the problems of territorial integrity of states, interference in their internal affairs on the part of multinationals and various international organizations, the planting of alien moral values. The main conclusion, which prevails in the assessment of modern globalization processes and forecasting their future, is as follows: at the moment there is an urgent need to understand globalization processes compatible with ensuring the economic security of individual States and the international community as a whole.

\section{Economic security as an international phenomenon}

The changes in the international situation marked the beginning of new approaches in the field of political, economic and military relations of the countries of the world community. Under these conditions, state security is closely linked to economic issues. However, as the threat of war in the modern world is not completely removed, with particular acuteness there is a problem of security of the state and practical steps in this direction.

The urgency of the problem is due to a number of circumstances, internal and external. This is, firstly, a complication of internal economic, social and political problems in a number of countries: the state budget deficit, unemployment, rampant "shadow economy" and other negative effects of production decline, political instability and worsening social tensions. Secondly, in the context of a weakening of some countries intensified the desire of other powers to the military and technological superiority over them, the use of "economic instruments" pressure to achieve their political interests. Thirdly, it is vitally important compliance issues are a balance between the positive and negative sides of the impact of foreign economic relations of the course and the pace of socioeconomic reforms, as well as ensuring national defence.

One of the most important tasks of any state in the moment is to achieve such a level of security that would ensure internal stability, the country's active participation in international division of labour and at the same time it would guarantee national security. The economic security of the state - an integral part of national security, which is defined as the state of protection of the national economy from external and internal threats, with which it is able to ensure the progressive development of society, its economic and socio-political stability in the conditions of existence of unfavourable external and internal factors (Hordyenko). As noted Gogvud B.V and L.A Gang (Hohvud, 2004), the economic security of the state is determined by the level of development of the productive forces and the state of socio-economic relations, the development of scientific and technical progress and the use of its achievements in the national economy, foreign trade exchange and international situation. The material is basis for economic security components of development of the productive forces capable of providing expanded reproduction, civilized standard of living of citizens and economic independence of the state. The economic security of the State responsible not only for successful economic development, but also the need to establish the protection of national economic interests is arrangements.

In essence, the theory and practice of economic security policy before the start of the 90s was armed with a single country in the world - the United States. As it was established, neither Western Europe nor Japan has not recovered, "economic security" of the common foreign economic policy, even though the external economic 
block is sometimes present as a separate component of a more general doctrine of "comprehensive national security", for example, in the foreign policy practice of Japan's early 80 -ies. The same as this unit is included in each of the three concepts of China's national security, which together make up what is called in China, Deng Xiaoping Theory.

Analysis of more than 20 definitions of "national economic security", formulated by economists of the former Soviet republics, the definitions of the Hungarian official documents, Poland, Lithuania, as well as more than 10 definitions given by scientists in developed countries (USA, Canada, Japan, Germany, France, Spain) shows that for each group of countries characterized by the use of different approaches. Thus, in the post-Soviet countries, the majority of the definitions of "national economic security" is given by "interests" in post-socialist countries - through measurement of "international security", in developed countries - through the concept of "sustainability". This is understandable. Problems of market transformation, combined with the integration of national economies into the world economy, as well as the establishment of democratic institutions in the postSoviet countries have deeper roots than in the EU member countries. In countries with developed market economies, such problems are virtually absent (Kolupaev, 2012).

International economic security is defined "as that state of the world economy, which to the greatest extent meets the economic interests of the US in general." Despite the indisputable US leadership in the world economy, however, in Washington suggest that the US made efforts to ensure the country's national interests, including its economic aspects, inadequate.

It is now very actively discussed the idea of forming a special Economic Security Council or the UN (Security Council type), or as an independent international organization aimed at organizing and coordinating all international economic institutions such as "7", the WTO, the IMF, OECD and so on. As the main financier of the organization will be the United States, according to its end use must be determined, first of all, the economic interests of the USA (Annual Report).

\section{Threats to economic security}

As the subjects economic security threats serve those parts of the economic system, the parameters of which can go beyond the limits. Substantiality as security objects can act objects, processes and properties of both qualitative and quantitative parameters of objects and processes. The qualitative is characteristics of the economic security of objects characterized by different quantitative indicators (LEDs). This allows you to define the criteria of economic security through the establishment of the boundary values of economic security indicators. Raising these thresholds means security decline to an unacceptable level for the corresponding object.
Threats in the economy are complex. To understand them, it's a lot of threats should be streamlined by classifying them based on certain principles. These principles classifying threats interests in the economic sphere are (Orlova, 2013):

- Universality, that is, the fullest possible coverage of the whole set of threats to vital economic interests in the formation of the totality, which is subject to classification. This unaccounted any threats can make their classification incomplete and, therefore, useless, since it is likely it becomes a situation where are any of the unrecorded threats will contain features that are not in the accepted classification;

- Completeness of the information that is the best representation of the content of each of the identified threats. Without such a representation cannot be set sufficiently clear classifications of threat and take it to any group and prioritize its elimination, neutralization or weakening;

- Practical importance is drawing of the classifier threats such their characteristics, which are important, above all, for the adoption of measures to eliminate, neutralize or mitigate these threats. It should be remembered that the use of the qualifier of any far-fetched, of abstract ideas about streamlining identified threats together vital economic interests will only lead to the fact that such a qualifier would be useless in practice;

- The importance and priority, that is, the establishment within each classification group degree of importance of each group went down in this threat, and on this basis, the establishment of threat for each priority in its elimination, neutralization or weakening. Classification of the most probable threats to economic security is presented in Table 1 (Nikulina, Chistnikova, Orlova, 2012).

Table 1

The most likely threats to economic security

\begin{tabular}{|l|l|}
\hline \multicolumn{1}{|c|}{ Sign classification threats } & \multicolumn{1}{c|}{ Types of threats } \\
\hline \multirow{2}{*}{ By direction of } & personality \\
\cline { 2 - 2 } By source & society \\
\hline \multirow{2}{*}{ By the probability of } & internal \\
\cline { 2 - 2 } external \\
\hline \multirow{2}{*}{ Relative to human activities } & real \\
\cline { 2 - 2 } By the nature of occurrence & potential \\
\hline \multirow{2}{*}{ By awareness } & subjective \\
\hline \multirow{5}{*}{ By the degree perception } & antural \\
\hline \multirow{3}{*}{ The scale of the action } & conscious \\
\hline & unconscious \\
\hline & inflated \\
\hline & adequate \\
\hline & understated \\
\hline & imaginary \\
\hline & general state \\
\hline & regional \\
\hline & local \\
\hline
\end{tabular}


Such a classification of threats interests in the economic sphere helps to reveal the reasons for the birth of such threats understand their content and to evaluate their intensity, helps organizations more effectively combat them.

\section{Economic Security Strategy}

Security Strategy is an important element of strategic planning in the field of national security - the basic document of the state security sector. On the basis of its decision-makers make important management decisions. Thus, according to V.P. Horbulin and Kachynskyj A.B. (Horbulin, Kachyns'kyj, 2007), economic security strategy should be aimed not only at ensuring the socio-economic and socio-political stability of society, but also to provide the national economy with the necessary resources; protection of export products; maintaining adequate living standards. At the same time one of the main priorities for the implementation of economic security strategy advocates the construction of system of state regulation in this area that is crucial to prevent the collapse of society.

Strategic planning of the security of the state is carried out to ensure a coordinated, targeted and effective activities of public authorities and local governments, civil society institutions, the armed forces, other formed in accordance with the laws of military units, law enforcement bodies and special services of the civil protection, defence -Industrial complex, other forces and security sector funds (Varnalij). They, on the basis of current legislation, must transform security policies in political action, legal, institutional, military and other measures for the implementation of national interests, first and foremost, to identify, predict, prevent and neutralize human security threats (citizen), society and state. That is, the performance of the developed strategic planning process and duly approved activities, according to G.P. Sytnyk (Sytnyk), must provide an adequate response to the threat to the national interests and readiness of the system of national security to perform its functions and tasks of the state to promote integration into the international and regional security.

Analysis of previous experience and research of the designated problem allows to allocate such directions to strengthen the economic foundations of the state security, such as:

1) Reforming the tax system, ensure that the fiscal policy of the state to reduce the proportion of all the components of material inputs in the economy;

2) Improving the efficiency of use of public funds; ensuring effective state control of activity of subjects of natural monopolies, the transparency of their use of financial resources, the efficiency of the tariff and regulatory policy; 3) The direction of economic policy measures to strengthen the financial condition of entities, ensuring their focus on increasing profitability and capitalization;

4) Promotion of exports, especially high-tech, along with the implementation of public policies, the need for advancing the expansion of the internal market, to avoid critical dependence of the national economy on world markets;

5) Improving the competitiveness of the national economy, which is not possible with the current is the level of innovation activity of enterprises and for which is necessary to form the national innovation system, the expansion of investment opportunities for the realization of innovative projects.

\section{The international experience of economic security}

Experience is large of EU countries - Germany and France. In France, the main state document, which addresses certain provisions of economic security, is the National Security Law in 1964.

In Germany, there is no such law. The main interests of the country in the field of national security, including its economic component, are presented in the form of official directives of the Ministry of Defence. Germany sees ensure their economic security in maintaining the economic and social progress, democratization in Europe and worldwide, the protection of economic blackmail, freedom of trade and access to raw materials and markets in the framework of a fair world economic system. Despite the fact that Germany is one of the largest consumers of imported raw materials, this fact is not considered as an economic security threat. While maintaining the achieved level of energy consumption seeks to achieve growth of industrial production and the increase in German export prices.

Still, the main focus of the EU countries are doing to ensure national security through the measurement of European security, not paying attention to such an important (such as the former post-Soviet or totalitarian countries) own capacities to ensure economic security. For example, in the aforementioned directive of the Ministry of Defence of Germany stated that "the problems of our complex world can be solved best through international discussion and compromise, so the German security policy focuses on international relations and supranational institutions." In other words, in Western Europe the economic security of the country is not understood as the pursuit of self-sufficiency and independence of the national economy or policy from the rest of the world, as well as a state of stable and sustainable economic and social development of the country, which can be achieved through close political and economic cooperation.

Experience Japan. In Japan, the transition from traditional security treatment in the military-political sense to the broad interpretation of the concept of security has occurred in the early 1970s, when quite clearly delineated signs the end of the era of unchallenged US economic supremacy on a global level and in some regions, especially in AsiaPacific region. Economic security for the Actualization of Japan was associated with another important aspect - with the desire to enhance the country's role in international 
affairs through the use of its power of the world's second economic power. The main obstacle to this goal was the economic vulnerability of Japan, due to the high level of external resource dependent, achieved at the time of $80 \%$. Based on this priority in national security it was made advancing economic development, trade-economic and scientific-technical cooperation with other states. Since then, national economic security has been allocated under which began to understand the ability of the economy to withstand any external threat.

Experience in the United States and Canada. According to the Information Centre of Canada, the strategic objective of the Government in the area of ensuring the economic security of the country is to maintain the conditions for long-term growth in labour productivity and capital, and thus - the standard of living, including a robust and dynamic business environment conducive to innovation, to attract domestic and foreign investment and sustainable economic growth.

The first national program of economic security can be called a memorandum to the United States, approved in 1990, with a view to taking appropriate measures to ensure economic security. In this document, as priority objectives additionally introduced the application of the national economic interests of the US to compete with rivals in the world arena and the protection of "the leading US position in the fields of technology" and "the preservation of the economic power of the United States" directly associated with carrying out measures to ensure the economic security.

Subsequently, the US president has repeatedly initiated the adoption of the Congress of various documents, which contain the names of the phrase "economic security." For example, the Act on the economic security of the United States in 1996 was dedicated to the information security of the United States, in particular, the fight against economic espionage. In this document, "economic security" is understood as a part of national security; it is aimed at strengthening the legal protection of information about innovations and innovations from foreign espionage, which are the basis for improving the competitiveness of the US economy.

Following the terrorist attacks September 11, 2000 there is a shift in emphasis in the contents offered to take to ensure the economic security of documents in the United States. So, to ensure the economic security of the package 2001 is mainly dedicated to the problems of workers losing their seats as a result of the destruction of buildings in New York, as well as the organization of social assistance to these citizens (in medicine, education). In this document, however, offered to revive the US economy measures that should allow for the construction of more buildings, lead to a reduction in unemployment and an increase in jobs; proposals to increase energy independence (separate energy plan), to reform the education system, to expand the markets for their products abroad.

The experience of small countries in Western Europe (Netherlands, Belgium, Denmark, Luxembourg,
Switzerland) to ensure the economic security shows that the main strategic objective for the protection of national economic interests them is to ensure sustainable economic growth and modernization of the economy in accordance with the conditions of competition on the world market. These countries are not able to significantly influence the formation of the structure of the world economy. They are forced to adapt to the conditions of the global economy, change the existing structure of national economies and the proportion of their development. From this derive strategic objectives of creating a flexible, efficient structure and specialization of the economy. Timely conducted structural reforms designed to enhance the competitiveness in foreign markets and mitigate the social consequences of structural change for the population of these countries.

The Baltic is countries and the countries of Central Europe. Czech Republic, Hungary, Poland, Slovakia and the Baltic States in the early 1990s, was elected virtually the same model of economic security, which included the following: an assessment of the geopolitical situation in the region; definition of the vector and development strategy; the alignment and implementation of behaviours', including in the economic sphere, in accordance with the dominant trends of regional and global evolutionary process; correlation of basic quantitative and qualitative indicators of development with global and regional standards; adjustment of the course of economic reforms.

The basis of their security policy course has been laid on the convergence of national interests and European interests; political, economic, institutional, cultural transformation, in accordance with Western standards.

The fundamental principle of the concept of the Hungarian security policy is that security cannot be reduced only to the political and military; it increases the importance of economic factors. The main element of the Hungarian concept is the concept of the integrated nature of the security, including its economic component: no state is cannot is strengthening their security at the expense of another state; security can be comprehended and provided only in terms of cooperation. On this basis, the Hungarian security policy rests on three fundamental pillars: political, military and economic integration with Western Europe. The second fundamental of basis of Hungarian security policy are the opportunities offered by regional cooperation within the Visegrad Group, Central European Initiative, as well as bilateral relations.

The main threats to the economic security of Hungary, as noted in the concept are: underdevelopment regions of Central and Eastern Europe from Western European countries, the difficulties of transition to a market economy, problems of formation of democratic institutions. In Poland, the Hungarian concept to economic security threats listed above added another - the cessation or significant restriction of imports of strategically important raw materials. 
Post-Soviet countries. The analysis of publications shows that Ukraine, despite the peculiarities of foreign policy, is under the dominant influence of Russian developments in the sphere of economic security. Equally, this applies to Georgia and Kazakhstan.

\section{Conclusions}

Without economic security of the state cannot be sustainable development of the economy and the welfare of citizens. The protection of the national interests is the formation of an economic security strategy - the most important functions of the state, the implementation of which is impossible without a system of self-regulation mechanisms and regulation. The government should implement a set of measures to promote economic growth, and that will guarantee the economic security of the country. These measures should cover all sectors of the economy. These measures include the implementation an active structural and social policies, enhancing the activity of the state in investment, financial, monetary and foreign economic sphere, the continuation of institutional reforms.

The difference between the used methodological approaches to ensure the economic security of the EU member states and CIS countries due to the fact that the first group of countries is focused on standards and borrows the experience of the leading EU countries (Germany, France), and the second group, located in the zone of influence of Russia (Moldova, Ukraine, Belarus, Kazakhstan), - on the Russian developments and standards. In turn, Russia in their design focuses more on standards to ensure economic security, which have been made in the period of the Soviet Union.

The main strategic goal of countries in Western Europe, the USA, Canada and Japan in the field of protection of national economic interests is to ensure sustainable economic growth and modernization of the economy in accordance with the conditions of competition on the world market.

\section{References}

Hordyenko, D.V. Osnovy ekonomycheskoj bezopasnosty hosudarstva. [Electronic resource]. - Retrieved from: www/csef.ru

Hohvud, B.V., \& Han, L.A. (2004). Analiz polityky real'noho svitu. - K.: Osnovy, 396 p.

Kolupaev, V.A. (2012). Formirovanie koncepcii nacional'noj jekonomicheskoj bezopasnosti v zarubezhnyh stranah. Belorusskaja jekonomika: analiz, prognoz, regulirovanie. Jekonomicheskij bjulleten' NIJeI Minjekonomiki $\mathrm{RB}$, № 12 , p. 2-9.

Annual Report to Congress on Foreign Economic Collection and Industrial Espionage, July 1995. - Internet.

Orlova, A.V. (2013). Ugrozy jeconomicheskoj bezopasnosti. Modern Directions of Theoretical and Applied Researches, 2013.

Nikulina, E.V., \& Chistnikova, I.V., \& Orlova, A.V. (2012). Economic region potential. Scientific reviewed magazine «Scientific sheets BSU History Political science economy». - Belgorod: ID “Belgorod”, № 13 (132), p. 60-66.

Horbulin, V.P., \& Kachyns'kyj, A.B. (2007). Systemno-kontseptual'ni zasady stratehii natsional'noi bezpeky Ukrainy. - K. : DP "NVTs "Yevroatlantykinform", 592 p.

Varnalij, Z. Problemy ta shliakhy zabezpechennia ekonomichnoi bezpeky. [Electronic resource]. - Retrieved from: http://www.rainbow.gov.ua/news/25.html

Sytnyk, H.P. Bezpeka derzhavy kriz’ pryzmu osoblyvostej suchasnoho etapu tsyvilizatsijnoho rozvytku. [Electronic resource]. - Retrieved from: http://nationalsecurity.org.ua/category/library

\section{Татьяна МОМОт, Нина АВАНЕСОВА}

\section{СИСТЕМАТИЗАЦИЯ МЕЖДУНАРОДНОГО ОПЫТА ОБЕСПЕЧЕНИЯ ЭКОНОМИЧЕСКОЙ БЕЗОПАСНОСТИ ОБОСТРЕНИЯ УГРОЗ И ВЫЗОВОВ НОВОГО ТИПА ДЛЯ НАЦИОНАЛЬНОЙ И МЕЖДУНАРОДНОЙ БЕЗОПАСНОСТИ}

Аннотация. Цель работы состоит в систематизации международного опыта обеспечения экономической безопасности, как с точки зрения отдельных государств, так и для мирового хозяйства в целом. Постановка такой цели связана с нарастанием глобализационных и интеграционных процессов в мировой экономике, которые несут новые угрозы экономической безопасности. Методика. Теоретической и методологической основой исследования стали научные положения и выводы по проблемам обеспечения экономической безопасности на уровне мирового хозяйства в целом и отдельных национальных хозяйств в частности. При этом использовались такие общенаучные и специальные методы, как анализа и синтеза, сравнения, обобщения, адаптации. Результаты исследования позволили сделать вывод, что защита национальных интересов и формирование стратегии экономической безопасности - важнейшие функции государства, реализация которых невозможна без системы механизмов саморегулирования и регулирования. Государство должно осуществить комплекс мер по обеспечению экономического роста, что и будет гарантией 
Vol. 2, No. 1, 2016

экономической безопасности страны. Эти меры должны охватить все сферы экономики. В число этих мер входят осуществление активной структурной и социальной политики, усиление активности государства в инвестиционной, финансовой, кредитно-денежной и внешнеэкономической сфере, продолжение институциональных преобразований. Практическое значение состоит в выделении отличий используемых методологических подходов к обеспечению экономической безопасности в странах-членах ЕС и странах СНГ. Это объясняется тем, что первая группа стран ориентируется на стандарты и заимствует опыт ведущих стран Европейского Союза (Германии, Франции), а вторая группа, находящаяся в зоне влияния России (Молдова, Украина, Беларусь, Казахстан), - на российские разработки и стандарты. В свою очередь, Россия в своих разработках ориентируется больше на стандарты обеспечения экономической безопасности, которые были достигнуты в период существования СССР. Значение/оригинальность. Полученные результаты позволили определить основную стратегическую цель стран Западной Европы, США, Канады и Японии в области защиты национальных экономических интересов, под которой понимается обеспечение устойчивого экономического роста и модернизации экономики в соответствии с условиями конкурентной борьбы на мировом рынке. 